\title{
THE USE OF THE CUIRASS RESPIRATOR DURING LARYNGOSCOPY AND BRONCHOSCOPY ' UNDER GENERAL ANAESTHESIA ${ }^{1}$
}

\author{
G. E. Sleath, M.D., and H. B. Graves, M.D. ${ }^{2}$
}

LARYNGOSCOPY AND BRONCHOSCOPY are unique in that the operator, by virtue of the procedure itself, interferes with the patient's airway. All anaesthetic methods and techniques are designed to eliminate the anaesthetist and apparatus from the operative field, while at the same time interfering with the patient's airway and ventilation as little as possible.

Local anaesthesia would seem to be a logical method, and is probably more widely used than any other $(1,2)$. But it is not without danger: overdose and too rapid administration cause many fatalities. Also, with local anaesthesia patients experience a certain amount of discomfort, and the operator does not benefit from the relaxation obtained along with general anaesthesia.

With general anaesthesia most methods have to sacrifice ventilation for relaxation. Some procedures use a partial paralytic technique $(2,3)$. Others use relaxants and insufflate or ventilate through the side-arm of the bronchoscope $(4,5,6,7)$.

The present paper describes the experiences of the anaesthetic staff of the Vancouver General Hospital with a method that thebretically provides maximum relaxation with maximum ventilation.

\section{Method}

Toker (8) in 1955 was the first to describe the technique of combining a general anaesthetic of thiopentone sodium and succinylcholine with the use of a KIFA Cuirass respirator for bronchoscopy. A similar technique with a Nonaghan respirator was used by Green and Coleman (9), and Bayuk (10) in 1957 commented on the problems met with the use of the technique and the Emmerson respirator.

In our series of cases, the Technicon-Huxley chest-abdomen cuirass respirator Was used, not because it was believed superior to other similar models, but betause it was the model available (Fig. 1). In this type, negative pressure is applied to the external portion of the body enclosed therein. The cuirass is supplied in four sizes. It is sealed to the body from the upper anterior thorax at the clavicle, curves down beneath the arms, and continues at the lateral rib area in a straight line past the crest of the ilium and completes the seal across the pubic area. The area enclosed is the entire anterior breathing surface of the body, including both the chest and the abdomen. It is constructed of opaque plastic, flexible but practically unbreakable. A soft sponge-rubber gasket is attached to the outer edge of the shell to fill the crevices which might allow leakage.

1Presented at the Western Regional Meeting of the Canadian Anaesthetists' Society, Calgary, Alta., March 13-15, 1958.

2Department of Anaesthesiology, Vancouver General Hospital and Unıversity of British Columbia. 


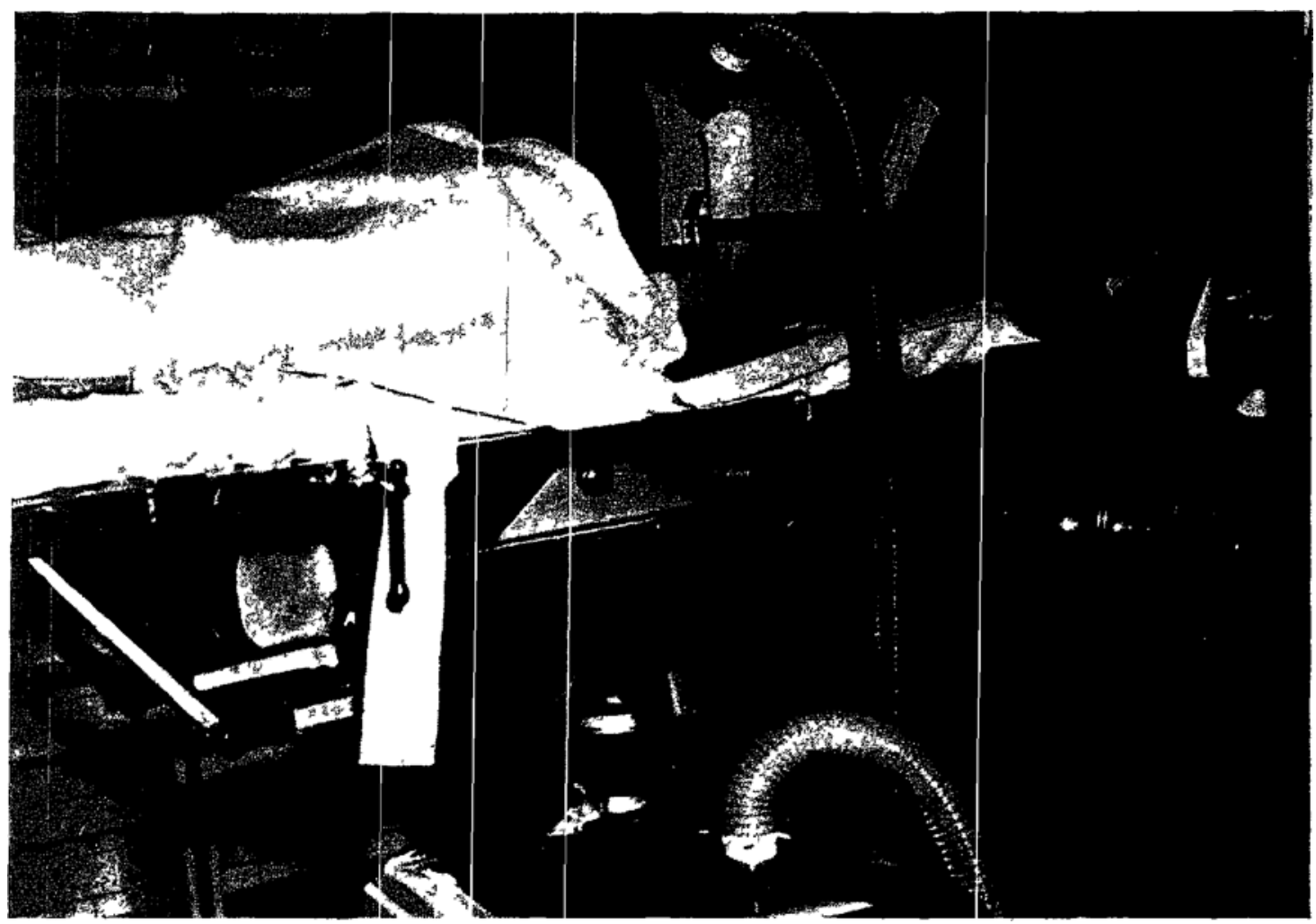

Figure 1 , The cuirass respirator applied to the patient on the operating table.

At the lower end of the currass on each side there is an adjustable supporting leg attached to a plastic ball which rests on the table These legs are designed to accommodate the height of the abdominal area and also to elıminate pressure of the currass on the body with the application of negative or positive pressure.

On applying the curass one places the lower end between the crests of the ihum and the pubic crest, allowing the upper end to rest upon, or directly below, the clavicle.

With the larger sized currass, it was found that the two legs often slid off the edge of the operating table during the phase of negative pressure, and also that the mattress on the table allowed considerable vertical movement of the legs when the cuirass was operating. It was found convenient to insert under the patient's buttocks a piece of half-inch plywood, measuring six by twenty-four inches, with three-quarter inch holes at intervals along its length, to accommodate the plastic balls on the ends of the legs and thus elimunate the movement.

Pressures may be set anywhere between 0 and $40 \mathrm{~cm}$. of water, both negative and positive, and the respiratory rate may be varied from 12 to 26 per minute.

Preoperative medication consists of meperidine or molphme and hyoscine or atropine in a dosage appropriate to the patient's age and condition

When the patient arrives in the operating room, his blood pressure is checked and an. intravenous infusion of 5 per cent dextrose in water is started, usually in the patient's left arm. The cuirass of suitable size may be placed on the patient at this point, and the straps apphed. The supporting legs are adjusted, the ply- 
wood board is placed beneath the patient's buttocks, and the plastic balls are located in two convenient holes The power unit is plugged in and c recked. and the hose is connected to the cuirass

The anaesthetic is commenced with $2 \frac{1}{2}$ per cent thiopentone into the intravenous drip. From 200 to $500 \mathrm{mg}$ will be used to produce unconsciousness. A suceinylcholine drip, ${ }^{3}$ with $200 \mathrm{mg}$ per $250 \mathrm{cc}$, or $500 \mathrm{mg}$ per $500 \mathrm{cc}$ bottle, is begun The patient is assisted with oxygen by mask from the gas machine untl respurations cease The respirator is then turned on and adjusted to a suitable pressure and rate The larynx may or may not be sprayed under direct vision with 2 per cent Pontocame ${ }^{\circledR}$ or 4 per cent Xylocane ${ }^{\circledR}$ at this stage The arrway is maintaned by support of the chin, or by unsertion of a rubber airway until the operator is ready to begin The adequacy of the exchiange is checked by placing the mask of the gas machıne on the patient's face and noting the amount of movement of the rebreathing pag. It is imperative that the exchange be adequate before the operator begins, and if it is not, the fit of the cuirass, the amount of negative pressure applied, or the ventilating rate must be adjusted until an estimated 400-500 cc. exchange is provided. The succonylcholine drip is regulated to maintain relaxation and apnoea, and intermittent doses of thiopentone are given as necessary. It may be difficult to determine when to use additional thiopentone other than giving it from experience according to the age and build of the patient and the time involved in the operative procedure An additional guide for more is a marked increase in blood pressure It is advisable to give oxygen at $500 \mathrm{cc}$ to 1 litre per minute flow by naso-pharyngeal catheter during laryngoscopy, or through the side-arm of the bronchoscope during bronchoscopy.

For these procedures an extra pair of hands greatly faclitates matters A resident to watch the arrway and preserve adequate ventilation of the patient allows time for careful adjustment of the respirator

Durng the endoscopy the co-operation of the operator is necessary We believe the procedure should not be unduly prolonged, especially if it is being done in semi- or total darkness There is perhaps a tendency on the part of the operator to make unnecessary explorations and demonstrations, encouraged by, the ideal working conditions and seemingly simple anaesthetic technique

When the procedure is completed, the succonylcholine drip is discontnued, and the respirator stopped The mask from the gas machine is apphed to the patient's face and oxygenation is mantained until spontaneous respiration is adequate.

\section{ResUlts}

From the middle of 1955 to date, this technique has been used. m two hundred cases at the Vancouver General Hospital At the present time it is used routinely for all individuals that can be fitted with a currass, that is, for patients down to about ten to twelve years of age From Table I, it can be seen that most are adults from thirty to seventy years of age. In the older age groups laryngoscopy for suspected carcinoma is the common procedure, with or without biopsy.

3Anectine (Burroughs Wellcome) 
Almost three tımes as many laryngoscopies as bronchoscopies appear in this series, for many bronchoscopies are still done under local anaesthesia (Table II).

About 75 per cent of the procedures are of relatively short duration, lasting under one-half hour. Only two cases in the serres extended over one hour (Table III)

TABLE I

Nuimer of Cases according to Aige Groups

\begin{tabular}{cc}
\hline Age (years) & Number \\
\hline $0-16$ & 10 \\
$16-30$ & 12 \\
$30-40$ & 39 \\
$40-50$ & 36 \\
$50-60$ & 49 \\
$60-70$ & 39 \\
$70-80$ & 15 \\
\hline
\end{tabular}

TABLE II

Number of Cases according to Procedures

\begin{tabular}{lc}
\hline Procedure & Number \\
\hline Laryngoscopy & 64 \\
Laryngoscopy and Bopsy & 63 \\
Laryngoscopy and Polypectomy & 21 \\
Bronchoscopy & 52 \\
\hline
\end{tabular}

TALLE III

Number of Cases according to Anaesthetic Tumes

\begin{tabular}{cr}
\hline Time (minutes) & Number \\
\hline $0-30$ & 146 \\
$30-60$ & 52 \\
$60+$ & 2 \\
\hline
\end{tabular}

Intubation.was resorted to for six of the patients in this series In three, intubation was performed for a tracheotomy at the end of the laryngoscopy. In one, intubation was carried out for biopsy of a large pharyngeal mass following the laryngascopy. In two patients ventilation was ineffective because of large carcinomatous masses, and intubation was performed to secure a better airway One of the latter required a tracheotomy forty-eight hours postoperatively

\section{Comments}

In any technique there are advantages and disadvantages, and this one is no exception

\section{Advantages}

Thiopentone and succinylcholne with a cuirass respirator provide a safe, general anaesthetic technique. The combination is non-explosive, eliminating hazards from the breakage of instrument bulbs or from short circuits. Complete 
paralysis is provided, eliminating the muscular resistance of the patient's jaw and neck. Paralysis and abduction of the vocal cords facilitates instrumentation and the performance of biopsies and removal of tumors. Adequate oxygenation and removal of carbon dioxide is ensured Colher and Affeldt (11) have shown in patients totally paralysed,from chronic poliomyelstis that at $-28 \mathrm{~cm}$ of water the chest-abdomen cuirass would provide sufficient reserve as calculated as one standard deviation above the theoretical tidal volume Kelleher et al (12) found that the Monaghan and KIFA cuirass respirators provided 300 to $500 \mathrm{cc}$ tidal volume in paralysed pohomyelitis patients if $15 \mathrm{~cm}$ of water negative pressure was used It has been shown by arterial plasma carbon dioxide determinations that tidal volumes of 250 to $400 \mathrm{cc}$. with a minute volume of 8 litres provided adequate alveolar ventilation (13) We have felt that we could produce adequate ventilation using pressure varying from 12 to $22 \mathrm{~cm}$ water. However, this was only a clinical impression, as no measures of tidal volume or blood oxygen and carbon dioxide levels were taken

Recovery from the procedure is rapid, provıding early return of protective reflexes At no time after the endoscopy is commenced, need the anaesthetist enter the operative field The equipment does not encroach into the region of the head and neck, and the currass on the chest should not interfere with the manipulation in any way

\section{Disadvantages}

The disadvantages are relative, and are common to most mechanical devices

First, it is often defficult to get a good fit with the currass Any leak around the shell interferes with the ventilatory efficiency In very obese patients, fat may be drawn up into the cuirass, filling it almost entirely, and thus leaving no room for the motion of abdominal contents, diaphragm and chest cage

Adequate ventilation in emphysematous patients is often difficult to obtain The positive phase of the cycle avalable with the machine does not seem to improve the situation clinically

The use of the respirator involves the extra labour of setting it up, and the fitting of the currass It might alarm some patients to have the shell placed on them before they were asleep Additionally, of course, there is the initral expense, of the respirator.

In our series of cases a most constant finding was an elevation of blood pressure, and occasionally of the pulse, during the procedure Any of four factors may be involved in this pressure rise.

(a) If the exchange is inadequate for any reason, carbon dioxide buld-up would occur

(b) Succinylcholine itself may produce a pressure rise, probably as a result of sympathetic ganglionic stımulation.

(c) Instrumentation of the larynx under light anaesthesia may produce a marked vasopressor response King et al. (14) found an average elevation of 53 $\mathrm{mm}$. mercury systolic and $34 \mathrm{~mm}$ mercury diastolic rise in forty-six patients durng intubation with thiopentone and curariform diugs. These pressor responses occurred also in patients who were conscious and intubated awake (15), 
but were less promment if instrumentation was performed in deeper planes of anaesthesia.

(d) If topical anaesthesia is used, a rise in pressure and pulse rate may occur, presumably owing to the action of the systemically absor bed anaesthetic agent upon the cardiovascular system (15). This vasopressor response was not found subsequently to be detrimental to any patient, but did cause some concern at the time of the procedure.

Bradycardia and pulse irregularities did not appear unless the patient had become obviously hypoxic from interference with the airway or from ineffective use of the respirator

Severe muscular pan, especially of the pectorals and jaw was complained of postoperatively by a few patients It 1 s believed that this is due to giving the succinylcholine too rapidly

\section{SUMMARY}

A method of performing laryngoscopies and bronchoscopies with thiopentone, succinylcholine and a currass respirator is described. Our expenences with two hundred cases are summarized Some advantages and disadvantages of the technique are outlined.

\section{RÉsumé}

Avec presque toutes les méthodes d'anesthésı générale employées pour les laryngoscopies et les bronchoscopies, il faut sacrifier la ventılation en faveur du relâchement muscularre Dans ces circonstances, théorıquement, l'emplor du respirateur à currasse pourrait procurer à la fors une ventilation maxıma et un relâchement musculaire maximum Depuss la dernière mortié de l'année 1955, au cours de 200 cas de bronchoscopies et de laryngoscopies, les auteurs ont employé le respırateur currasse, thorax-abdomen, Technicon-Huxley.

On a donné comme prémédication de la meperıdine ou de la morphine et de l'hyoscine ou de l'atropine à des dosages appropriés. A l'arrıvée à la salle d'opération, on a installé une solution de $5 \%$ de dextrose dans une currasse, de g̀randeur convenable en ayant soin de placer l'extrémité inféneure de cette currasse sur une planche de bois laminé placée sous les fesses du malade afin d'éviter un raouvement vertıcal On a commencé l'anesthésie en injectant dans la tubulure du sérum du thiopentone à $2 \frac{12 \%}{2}$, on en a employé de 200 à $500 \mathrm{mg}$ pour maintenrr un état d'inconscience Puss, on a commencé un goutte à goutte de succinylcholıne $(1 \mathrm{mg} / \mathrm{ml})$ en assistant la respination du malade avec de l'oxygène amené par la machıne à anesthésıe et, cela, jusqu'à ce que la respiration cesse Alors on a mis le respirateur en fonctionnement et on la ajusté à un rythme et à une pression convenables. A ce moment, 1 l est facultatif d'arroser le larynx sort avec de la Pontocame à $2 \%$ ou de la Xylocame à $4 \%$. Les voiés respuratorres sont maintenues libres en supportant le menton du malade et en plaçant un tube pharyngé en attendant que le chırungıen soit prèt à procéder; on peut contrôler l'efficacité des échanges respiratorres en plaçant le masque de la machıne à anesthésie sur la figure du malade et en notant le 
nombre et l'amplitude des mouvements du ballon. Le respirateur doit produre des échanges de 400 à $500 \mathrm{ml}$.

On provqque l'apnée et le relầchement musculaure par le goutte à goutte de succinylcholine et linconscience par des doses intermittentes de thiopentone. Pour la laryngoscopie, on donne de l'oxygène par des catheters nasaux et pour la bronchoscopie, on donne l'oxygène par le tube latéral du bronchoscope.

Les avantages de ce procédé sont l'usage d'un mélange non explosif et, tout en donnant un relâchement complet, il mantıent une ventılation adéquate. Le réveil est rapide et les réflexes protecteurs réapparaissent précocement

Chez les emphysemateux, 1 est souvent dufficile de procurer une ventilation adéquate. On peut s'attendre à rencontrer des difficultés, chez certains malades, pour ajuster la cuirasse et, chez les personnes grasses, il peut arriver que la graisse solt aspurée dans la currasse et la remplisse complètement.

\section{REFERENCES}

1. Churchill-Davidson, H C Anaesthesia for Bronchoscopy Anaesthesia 7 237-242 (1952).

2 Anaesthesia in Broncho-Esophagology A Panel Discussion Trans Am Broncho-Esophago$\log _{1}$ cal Ass , 1955, pp 50-72

3. Wrant, G. M., Dobkin, A B , \& Kruduff, C J Problems of Anaesthesia for Bronchoscopy, Canad. M A J 76 1011-1015 (1957).

4. Shane, S M, \& Ashman, H A Method of General Anaesthesia for Bronchoscopy and Bronchography A M A Arch Otol 62 319-321 (1955)

5. Kovacs, S. Method of Ventilation during Bronchoscopy Anesthesiology 18 335-336 (1957).

6 Boone, G. D. A Technique of Intravenous Pentothal Sodium Succinylcholine Anesthesia for Bronchoscopy and Bronchògraphy (A Report of 600 Cases). Arız Med 13 352-356 (1956).

7 Alver, E C, \& Leek, J. H Induced Paralysis for Endoscopic Procedures A M A Arch Otol 62. 399-405 (1955)

8. Toker, P. Anesthesia for Bronchoscopy Use of Respirator South African M J 29 $40-41$ (1955).

9 Green, R. A, \& Coleman, D J Curass Respurator for Endoscopy Anesthesia 10369 373 (1955)

10 Bayuk, A. J Chest Respirator for Bronchoscopy and Laryngoscopy Anesthesiology 18 135 (1957).

11. Collier, C. R, \& AfFeldT, J E. Ventilatory Efficiency of the Cuirass Respirator in Totally Paralysed Chronic Polıo Patients. J Appl Phys 6 531-538 (1954)

12 Kelleher, W H, Kinnier, A. B , Russell, W R, \& Stott, F D Notes on Cuirass Respirators Bnt M. J 2 413-415 (1952)

13. Price, H. L, Connon, E. H, \& Dripps, R D Some Respiratory and Circulatory Effects of Mechamcal Respirators J Appl Phys 6 517-530 (1954)

14. King, B. D, Harris, L C, Grueifenstetn, F E, Elder, J D , \& Dripps, R D ' Reflex Circulatory Responses to Direct Laryngoscopy and Tracheal Intubation Performed during Surgical Anesthesia. Anesthesiology 12: 556-566 (1951)

15. Knga, B. D.; Elder, J D, Proctor, D. F , \& Dripps, R D Reflex Circulatory Responses to Tracheal Intubation Performed under Topical Anesthesia Anesthesiology 15 231$238(1954)$ 